\title{
Differences in tsunami generation between the December 26, 2004 and March 28, 2005 Sumatra earthquakes
}

\author{
Eric L. Geist ${ }^{1}$, Susan L. Bilek ${ }^{2}$, Diego Arcas ${ }^{3,4}$, and Vasily V. Titov ${ }^{3,4}$ \\ ${ }^{1}$ U.S. Geological Survey, Menlo Park, CA 94025, USA \\ ${ }^{2}$ New Mexico Tech, Socorro, NM 87801, USA \\ ${ }^{3}$ National Oceanic and Atmospheric Administration, Pacific Marine Environmental Laboratory, Seattle, WA 98115, USA \\ ${ }^{4}$ Joint Institute for the Study of the Atmosphere and Oceans, University of Washington, Seattle, WA 98195, USA \\ (Received January 18, 2006; Revised February 2, 2006; Accepted February 6, 2006; Online published February 17, 2006)
}

\begin{abstract}
Source parameters affecting tsunami generation and propagation for the $M_{w}>9.0$ December 26, 2004 and the $M_{w}=8.6$ March 28, 2005 earthquakes are examined to explain the dramatic difference in tsunami observations. We evaluate both scalar measures (seismic moment, maximum slip, potential energy) and finite-source representations (distributed slip and far-field beaming from finite source dimensions) of tsunami generation potential. There exists significant variability in local tsunami runup with respect to the most readily available measure, seismic moment. The local tsunami intensity for the December 2004 earthquake is similar to other tsunamigenic earthquakes of comparable magnitude. In contrast, the March 2005 local tsunami was deficient relative to its earthquake magnitude. Tsunami potential energy calculations more accurately reflect the difference in tsunami severity, although these calculations are dependent on knowledge of the slip distribution and therefore difficult to implement in a real-time system. A significant factor affecting tsunami generation unaccounted for in these scalar measures is the location of regions of seafloor displacement relative to the overlying water depth. The deficiency of the March 2005 tsunami seems to be related to concentration of slip in the down-dip part of the rupture zone and the fact that a substantial portion of the vertical displacement field occurred in shallow water or on land. The comparison of the December 2004 and March 2005 Sumatra earthquakes presented in this study is analogous to previous studies comparing the 1952 and 2003 Tokachi-Oki earthquakes and tsunamis, in terms of the effect slip distribution has on local tsunamis. Results from these studies indicate the difficulty in rapidly assessing local tsunami runup from magnitude and epicentral location information alone.
\end{abstract}

Key words: 2004 Sumatra Earthquake, 2005 Sumatra Earthquake, tsunami, tsunami generation, potential energy, slip distribution.

\section{Introduction}

The devastating Indian Ocean tsunami of December 26, 2004 was associated with dramatic local runup observations recorded by the International Tsunami Survey Team in northern Sumatra (see other papers in this volume). These and other observations have led many to ask whether this tsunami was anomalously large given the size of the earthquake. We attempt to answer this question and in addition compare the December 2004 tsunami with the tsunami produced by the $M_{w}=8.6$ March 28, 2005 earthquake. Although these two earthquakes occurred on the SumatraAndaman interplate thrust with similar focal mechanisms, focal depths, and epicenters only about $110 \mathrm{~km}$ apart (Ammon et al., 2005), they produced dramatically different tsunamis as measured by onshore runup measurements and far-field tide gauge records. The similarity in the earthquake parameters for these two events allows a direct examination of the effect rupture complexity has on tsunami generation and local runup.

We compare measures of tsunami generation using both

Copyright (c) The Society of Geomagnetism and Earth, Planetary and Space Sciences (SGEPSS); The Seismological Society of Japan; The Volcanological Society of Japan; The Geodetic Society of Japan; The Japanese Society for Planetary Sciences; TERRAPUB scalar and finite-source representations of the earthquake. The objective is to determine what information about the earthquake is needed to rapidly assess tsunami generation and local tsunami severity. For example, whereas much progress has been made to determine scalar seismic moment in the context of tsunami warning (e.g., Tsuboi et al., 1995; Tsuboi, 2000; Weinstein and Okal, 2005), there exists considerable variability in local tsunami runup relative to moment magnitude $\left(M_{w}\right)$ even after a comprehensive calculation is made using long-period seismic waves. In contrast, a rapid and accurate assessment of tsunami runup derived from seismic inversions of slip distributions is hindered by the time and effort that it takes to perform these inversions and the uncertainty in results that stem from, among other things, differences in inversion techniques and parameterization (Beresnev, 2003). By comparing different measures of tsunami generation for the December 2004 and March 2005 Sumatra earthquakes, and the 1952 and 2003 TokachiOki earthquakes, we can assess their performance in the context of tsunami warning.

\section{Background}

The December 26, 2004 earthquake started offshore northern Sumatra and propagated unilaterally to the north 


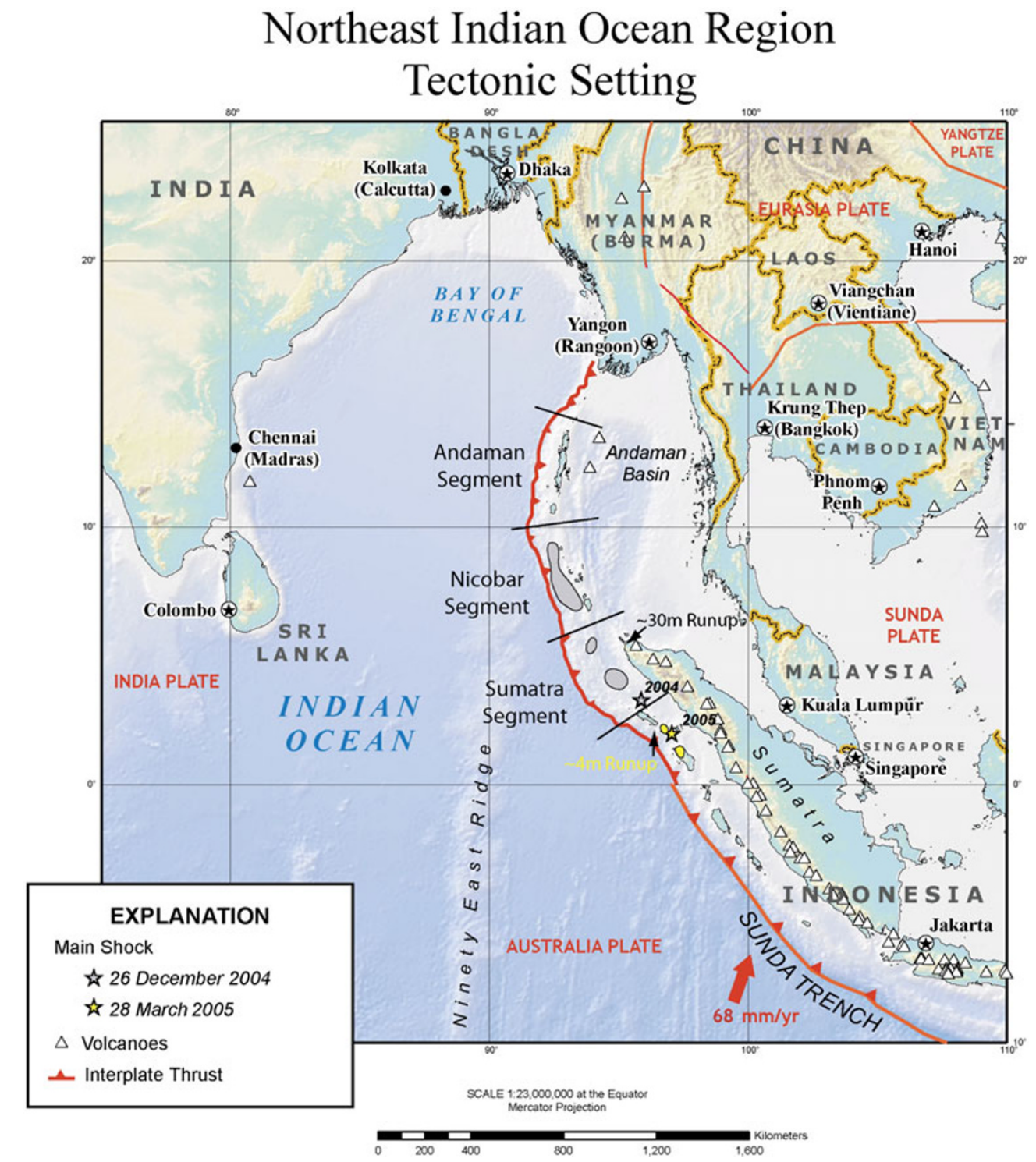

Fig. 1. Regional map of Sumatra and the Bay of Bengal, showing the epicenters (stars) and regions of high slip for the December 2004 earthquake (gray, representing regions of slip >10 m) (Chlieh et al., 2005) and March 2005 earthquake (yellow, representing regions of slip >5 m) (Ammon et al., 2005; Ji, 2005). For descriptive purposes, the December 2004 rupture is broken into three segments: Sumatra, Nicobar, and Andaman.

along the interplate thrust separating the downgoing India plate and the overriding Burma microplate-part of the larger Sunda plate (Fig. 1) (Lay et al., 2005). There is a high degree of complexity associated with the temporal and spatial patterns of rupture for this earthquake. Traditional pointsource measures of the earthquake include moment tensor inversions, from which the focal mechanism and scalar seismic moment can be estimated. The best-fit, focal plane from the Harvard centroid moment tensor (CMT) solution ( strike $=329^{\circ}, \operatorname{dip}=8^{\circ}$, rake $=110^{\circ}$ ), indicates thrust movement, with little oblique motion (Lay et al., 2005). The seismic moment for this solution is $M_{0}=4.0 \times 10^{22} \mathrm{Nm}$ $\left(M_{w}=9.0\right)$ for the 300-500 s period surface waves analyzed. Limitations of point-source measures for earthquakes of this size are discussed by Lay et al. (2005). Other longer period and static displacement measurements indicate that the earthquake is larger: $M_{w}=9.1$ to 9.3 (Banerjee et al., 2005; Ishii et al., 2005; Park et al., 2005; Stein and Okal, 2005; Tsai et al., 2005). Although the centroid from the Harvard CMT solution is located in the southern-most part of the rupture zone, substantial slip occurred farther to the north and may have not been fully accounted for in the seismic periods traditionally used in the CMT method.

The epicenter for the $M_{w}=8.6$ March 28, 2005 earthquake was approximately $110 \mathrm{~km}$ to the SE of the December epicenter (Fig. 1) and re-ruptured a portion of the interplate thrust that last ruptured in $1861(M \sim 8.3-8.5)$ and 1907 ( $M \sim 7.6$ ) (Newcomb and McCann, 1987). The hypocentral depth (approx. $30 \mathrm{~km}$ ) and focal plane for the March 2005 earthquake $\left(\right.$ strike $=329^{\circ}, \operatorname{dip}=7^{\circ}, \operatorname{rake}=110^{\circ}$ ) are very similar to that for the December 2004. The Harvard CMT seismic moment for the March 2005 earthquake is $M_{0}=1.1 \times 10^{22} \mathrm{Nm}$ (Lay et al., 2005).

Despite the similarity of these two earthquakes in terms of location and fault parameters, the tsunamis from these events were dramatically different. International tsunami survey teams (see other papers, this volume) reported local tsunami runups from the December 2004 event in excess of 
Table 1. Far-field peak-to-trough wave heights for the December 2004 and March 2005 tsunamis at selected tide gauge stations.* (See Fig. 5 for locations.)

\begin{tabular}{lccc}
\hline Station & $\begin{array}{c}12 / 26 / 2004 \\
\text { Peak Heights }(\mathrm{m})\end{array}$ & $\begin{array}{c}3 / 28 / 2005 \\
\text { Peak Heights }(\mathrm{m})\end{array}$ & Ratio \\
\hline Colombo, Sri Lanka & $>2.7$ & 0.5 & $>5.4$ \\
Hanimaadhoo, Maldives & $2.2^{\dagger}$ & 0.4 & 5.5 \\
Male, Maldives & 2.1 & 0.2 & 10.5 \\
Gan, Maldives & 1.4 & 0.3 & 4.7 \\
Cocos Is., Australia & 0.5 & 0.2 & 2.5 \\
\hline
\end{tabular}

*Information from Abe (2005) and Merrifield et al. (2005).

$\dagger_{\text {T }}$ sunami amplitudes partially blocked by India and Sri Lanka

$30 \mathrm{~m}$ at Lhoknga in the western Aceh Province. In contrast, survey teams have reported maximum tsunami runup of 4 $\mathrm{m}$ in the vicinity of the March 2005 epicenter (Jaffe et al., 2005). Thus, there is approximately an 8 -fold difference in maximum runup between the March 2005 and December 2004 tsunami, even though there is only a difference of 0.4 0.6 magnitude units between the two earthquakes. Below, we examine this difference in the context of other tsunamigenic subduction zone earthquakes and indicate other measures of tsunami generation in addition to seismic moment.

\section{Measures of Tsunami Generation}

Tsunami generation is caused by rapid movement of the seafloor over broad areas in comparison to water depth. For this reason, tsunamis can be treated as shallow-water waves. For earthquakes, we calculate the initial tsunami wavefield from the coseismic displacement field determined from slip along the fault, using equations derived by Okada (1985). We also account for the wave generation Green's functions that low-pass filters surface displacement wavenumbers $(k)$ by $(\cosh k h)^{-1}$, where $h$ is the water depth (Kajiura, 1963; Satake, 2002a; Ward, 2002). Because earthquake rupture speeds are substantially greater than tsunami phase speeds, coseismic displacement is often assumed to occur instantaneously for tsunami generation, although for long rupture durations, finite process times need to be considered. We account for finite rupture time in generating the December 2004 tsunami by applying a trapezoidal time function to the slip distribution, with a total duration of about $500 \mathrm{~s}$ (Ishii et al., 2005). We also account for the effect of horizontal coseismic displacements in regions of steep bathymetry on tsunami generation (Tanioka and Satake, 1996), although for most regions along the Sumatra-Andaman subduction zone, this effect is minor.

\subsection{Seismic moment}

Far-field tsunami amplitudes scale consistently with the scalar seismic moment of the earthquake $\left(M_{0}\right)$ (Pelayo and Wiens, 1992). Seismic moment estimates for the December 2004 earthquake are found to be dependent on the period of observation (Banerjee et al., 2005). If we use seismic moment estimates for the December 2004 earthquake that do not include significant post-seismic deformation then $M_{0}=6.5 \times 10^{22} \mathrm{Nm}$ (Model III, Ammon et al., 2005). This is approximately 5.9 times greater than the moment for the March earthquake $\left(1.1 \times 10^{22} \mathrm{Nm}\right)$ (Lay et al., 2005). The ratio of seismic moments for the two earthquakes is similar to the ratio of far-field tsunami amplitudes (Table 1), (a)

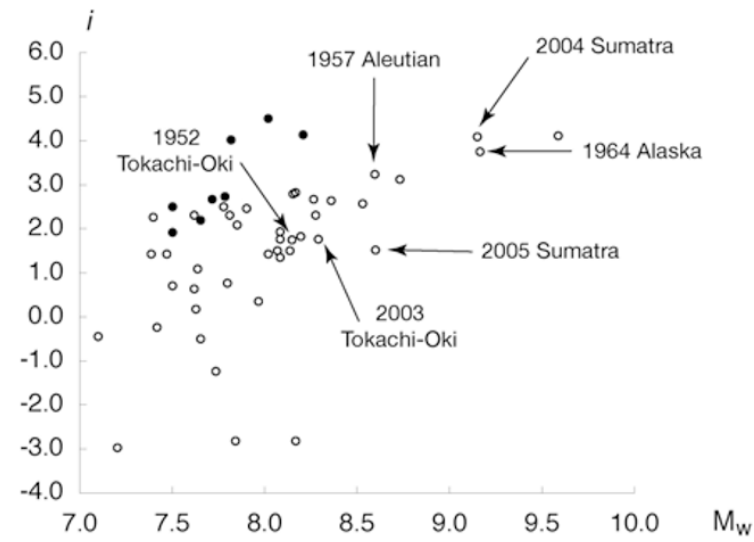

(b)

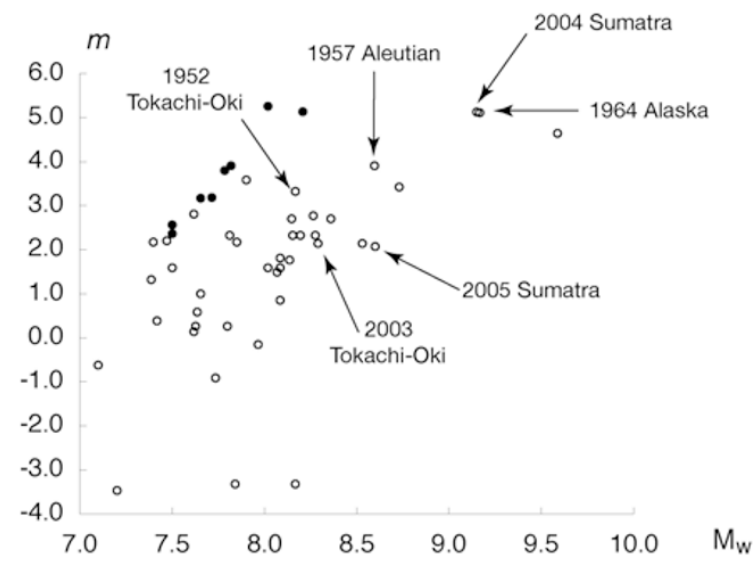

Fig. 2. Comparison of local tsunami runup for subduction earthquakes listed by Geist (2002), modified to include the 2004 and 2005 Sumatra earthquakes and the 1952 and 2003 Tokachi-Oki earthquakes. (a) Soloviev-Go intensity scale (i) based on mean tsunami heights (Soloviev, 1970); (b) Imamura-Iida magnitude scale (m) based on maximum tsunami heights (Iida et al., 1967). Solid circles: tsunami earthquakes. Only runup measurements within a $100 \mathrm{~km}$ perimeter of the aftershock zone are included.

although there are also significant effects associated with rotation of the tsunami beaming pattern as described below.

We place the difference in local tsunami runup between the December and March earthquake relative to $M_{w}$ in context with other subduction zone earthquakes in the Pacific (Fig. 2). Geist (2002) compiled local tsunami runup and wave height measurements from 46 earthquakes (18961996) and displayed the results using 2 tsunami scales: the Soloviev-Go intensity scale (i) based on mean tsunami heights (Soloviev, 1970) and the Imamura-Iida magnitude scale $(m)$ based on the maximum tsunami height (Iida et al., 1967). The results from the Geist (2002) compilation indicate that there is significant variation in local tsunami runup relative to $M_{w}$, even though $M_{w}$ is a fairly good predictor of far-field tsunami amplitude (Pelayo and Wiens, 1992). To this catalog, we add the results from the December 2004 and March 2005 tsunamis (Fig. 2), using the same definition for local tsunami measurements as in Geist (2002): 100-km perimeter around the aftershock zone.

Comparison of the Sumatra tsunamis to the entire dataset indicates that the December 2004 tsunami is very similar in terms of local tsunami magnitude or intensity relative to past earthquakes of the same size (Fig. 2). In particu- 
lar, the local tsunami for the December Sumatra earthquake is comparable to the $M_{w}=9.21964$ Great Alaska earthquake, even though 100-300 s period surface-wave amplitudes are about 3 times greater for the 1964 Alaska earthquake in comparison to the 2004 Sumatra earthquakes (Lay et al., 2005). This consistency is also evident in empirical relationships. Abe (1995) suggested that the maximum tsunami height near the source is given by twice the limiting tsunami height $(2 \mathrm{Hr})$, where

$$
\log H r=0.5 M_{w}-3.30
$$

applicable for interplate thrust earthquakes. Using this relationship and an estimate of $M_{w}=9.1-9.3$ (Banerjee et al., 2005; Park et al., 2005), the maximum tsunami height $(2 \mathrm{Hr}$ ) for the December tsunami is predicted to be 36-45 m, slightly greater (for the $M_{w}=9.1$ estimate) than the maximum measurements made by the International Tsunami Survey Team (34.8 m).

In contrast, the tsunami from the March 2005 earthquake is deficient in comparison to tsunamis with similar magnitude earthquakes (Fig. 2). On both magnitude scales, the March 2005 tsunami defines a new lower bound for this dataset; for comparison the $M_{w}=8.61957$ Aleutian earthquake (Johnson and Satake, 1993) produced a maximum tsunami runup of $15 \mathrm{~m}$ (Lander, 1996). Also, using the Abe (1995) relationship above, $2 \mathrm{Hr}=10 \mathrm{~m}$, much greater than the maximum observed runup of $4 \mathrm{~m}$. Geist (2002) suggested that the variability in local tsunami runup was most pronounced for $7<M_{w}<8.5$. As evidenced by the March earthquake and tsunami, this may be an artifact of too few measurements for large magnitude earthquakes. Significant local tsunami runup variability may indeed exist for $M w>8.5$.

Because tsunami generation is directly proportional to slip on the fault plane, it is also useful to compare slip estimates from seismic inversion results of the two earthquakes. Much of the variability of local tsunami runup with respect to $M_{w}$ may be caused by variability in the scaling relationship between average slip and $M_{w}$ (Geist, 1999). Regions of maximum tsunami runup have the tendency to be located directly across from regions of maximum slip, however, as in the case of the 1992 Nicaragua earthquake (Geist, 1999) and the Sumatra earthquakes (Fig. 1). For this reason, it useful to compare maximum slip estimates for the two earthquakes. Maximum slip for the December 2004 earthquake is approximately 15-20 m (Ammon et al., 2005) and approximately 6-10 m for the March 2005 earthquake (inversion below and $\mathrm{Ji}, 2005$ ), resulting in a factor of 1.5-3.3 difference between the two earthquakes. It is evident, therefore, that the ratio of maximum slip is substantially smaller than the ratio of maximum tsunami runup $(\sim 8)$ associated with the two earthquakes, indicating that other tsunami source parameters, such as depth of maximum slip, need to be considered in assessing tsunami generation potential.

\subsection{Potential energy}

As an alternative to seismic moment and slip, tsunami generation can be measured by the potential energy $\left(E_{T 0}\right)$ (Kajiura, 1981) derived from initial sea surface elevation $\left(\eta_{0}\right)$ over the area of the ocean $(S)$ surrounding the source region (i.e., onshore regions are excluded from the potential energy calculations): $E_{T 0}=\frac{1}{2} \rho g \int_{S^{\prime}} \eta_{0}^{2} d S$. Significant variations of potential energy relative to $M_{0}$ are caused by aspects of fault rupture that do not directly relate to seismic moment, mainly slip and dip angles, as well as focal depth (Kajiura, 1981). In particular, holding $M_{0}$ constant, $E_{T 0}$ will increase for events dominated by shallow slip. The total energy of a tsunami is equally partitioned between potential and kinetic energy, with elastic compressional energy in the ocean being negligible (Ward, 1980). In the absence of energy dissipation from breaking and bottom friction, this partition of energy is stable during propagation. For the runup process, however, potential energy increases to a maximum and kinetic energy decreases to zero at maximum indundation distance ( $\mathrm{Li}, 2000)$.

The initial sea-surface elevation $\eta_{0}(x, y)$ for the December earthquake is subject to uncertainty in rupture process (namely slip distribution and rupture extent). Using the coseismic vertical displacement field from a geodeticallyderived slip model (Chlieh et al., 2005), $E_{T 0}$ for the December earthquake is approximately $4.1 \times 10^{15} \mathrm{~J}$. Including horizontal deformation in vertical displacement of the sea surface (Tanioka and Satake, 1996) increases the estimate of $E_{T 0}$ for the December earthquake by approximately 2\%. For comparison, Lay et al. (2005) estimated $E_{T 0}=4.2 \times 10^{15} \mathrm{~J}$ for the December earthquake. In contrast, $E_{T 0}$ ranges from $1.0-2.1 \times 10^{14} \mathrm{~J}$ for the March 2005 earthquake, using seismic inversion results presented in the next section and from Ji (2005). Because subaerial regions (Nias, Simeulue, and Sumatra) overlie the March rupture zone, the tsunami potential energy for the March earthquake is reduced by about $17-26 \%$ in comparison to an equivalent region of uplift/subsidence that is completely submerged. For other historic $M>9$ earthquakes, Kajiura (1981) estimated the tsunami potential energy for the $M=9.2,1964$ Alaska earthquake as $2 \times 10^{15} \mathrm{~J}$ and for the $M=9.5,1960$ Chile earthquake as $1 \times 10^{16} \mathrm{~J}$. Thus, from a potential energy standpoint, the December 2004 earthquake is again similar to the 1964 Alaska earthquake, and both earthquakes have an order of magnitude greater tsunami potential energy than the March 2005 earthquake.

\subsection{Influence of water depth above the source region}

The primary hazard variable associated with tsunamis is runup which is dependent on the water depth above the source region. Standard scalar measures of seismogenic tsunami potential $\left(M_{0}\right.$ and $\left.E_{T 0}\right)$ do not distinguish whether seafloor displacement occurs in deep or shallow water. Near-field runup varies considerably with respect to $M_{0}$ for subduction zone earthquakes, owing primarily to the relative position of high slip regions with respect to the overlying water depth and regional propagation effects (Geist, 2002). Consider two cases of identical displacement of the seafloor: one that occurs in deep water and one in shallow water. Although the seismic moment and tsunami potential energy for both cases are the same, seafloor displacement under deep-water will result in larger near-shore tsunami amplitudes, owing to amplification according to Green's law which is valid for slowly varying water depth 
a)

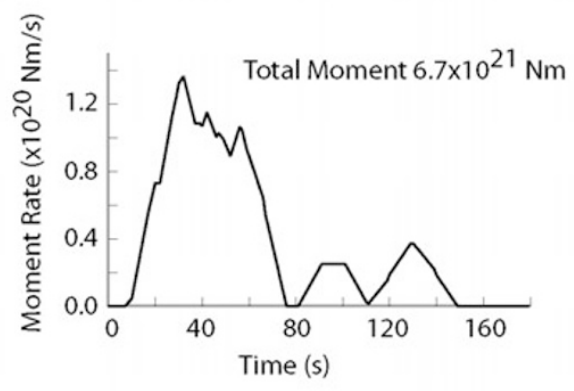

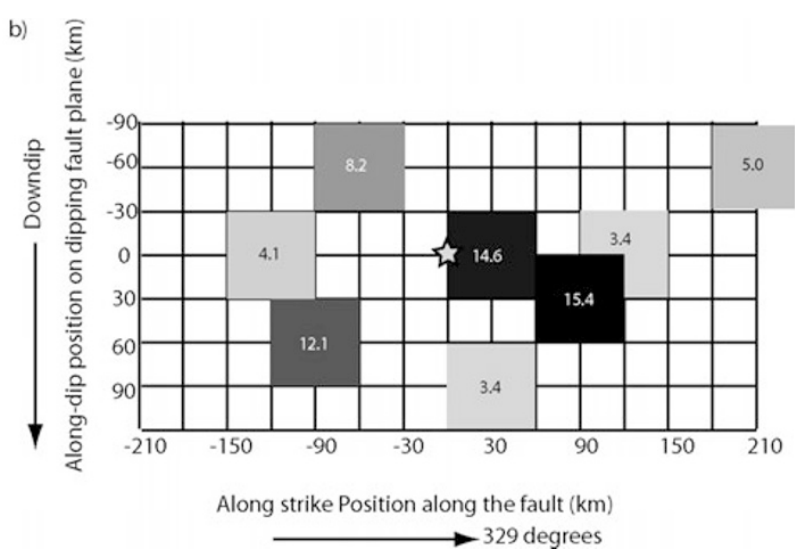

Fig. 3. Source time function (a) and moment distribution (b) of the March 2005 earthquake based on inversion of $P$ and $S H$ waves recorded at 13 teleseismic stations. Numbers within the blocks of $(b)$ indicate the moment release $\left(\times 10^{20} \mathrm{Nm}\right)$ within each block. The star indicates the position of the PDE hypocenter used for this inversion ( $97.01^{\circ}$ longitude, $2.07^{\circ}$ latitude, $24 \mathrm{~km}$ depth). Faulting geometry used for this inversion was taken from the Harvard CMT solution (strike $329^{\circ}$, dip $7^{\circ}$, rake $110^{\circ}$ ) (Lay et al., 2005).

(i.e., the WKB approximation) (pg. 71, Mei, 1989):

$$
\frac{\eta_{1}}{\eta_{0}} \sim\left(\frac{h_{1}}{h_{0}}\right)^{-\frac{1}{4}}
$$

where $\eta$ is wave amplitude and $h$ is water depth. Focusing and defocusing from refraction is not included in this formulation of Green's law (Satake, 2002b). Using the geodetic slip model for the December 2004 tsunami (Chlieh et al., 2005), the average water depth where uplift is greater than $3 \mathrm{~m}$ in the Sumatra segment is $1100 \mathrm{~m}$ and in the Nicobar segment is $2300 \mathrm{~m}$ (Fig. 1). In contrast, the average water depth where uplift is greater than $1.5 \mathrm{~m}$ for the March 2005 earthquake is $600-700 \mathrm{~m}$ (see next section). Aside from site-specific parameters (e.g., beach slope, $\beta$ ), runup is dependent on the amplitude, leading wave polarity, and wave steepness of the incident wave (Synolakis, 1987; Tadepalli and Synolakis, 1996). Runup associated with the deeper water source will not only be higher because of higher incident amplitudes, but also because the leading wave steepness will increase according to Green's law (Mei, 1989).

\section{Slip Distribution and Finite-Source Effects}

In addition to amplification and wave steepening described by Green's law, propagation effects from the source region to shore will be dictated by the regional bathymetry and include phenomena such as refraction, partial reflection off sharp changes in bathymetry, and wave trapping. In the near field, local maxima in sea floor displacement caused by heterogeneous distribution of fault slip results in complex propagation paths. In this section, we describe some of the effects of rupture heterogeneity in relation to the difference in tsunami generation between the two earthquakes.

The spatial and temporal distribution of slip throughout the $1300 \mathrm{~km}$-long rupture of the December 2004 earthquake was determined both from seismic and geodetic inversion results (Ammon et al., 2005; Banerjee et al., 2005; Chlieh et al., 2005; Ishii et al., 2005; Krüger and Ohrnberger, 2005). Although there are significant differences in the results, most are similar in that large amounts of slip occur in the southern rupture segment and near the Nicobar is- lands, with decreasing amounts of slip in the Andaman Islands segment. Of note, Slip Model III of Ammon et al. (2005) indicates that relatively low amounts of slip occurred near the hypocenter, with the largest slip patch $(\sim 15 \mathrm{~m})$ occurring between $4^{\circ}-5^{\circ} \mathrm{N}$ as rupture proceeded northward. Although details of slip near the trench is poorly resolved by these inversions, analysis of aftershocks suggests that the shallow interplate thrust may have ruptured during December 2004 earthquake (Newman and Bilek, 2005).

In contrast, the slip distribution for the March 2005 earthquake using an identical seismic inversion method as for the December earthquake (Slip Model III) indicates that the largest slip patch was concentrated at depth near the hypocenter (Ammon et al., 2005; Ji, 2005). We compare this result with the inversion of $P$ waveforms from 13 stations located at teleseismic distances, using the technique of Kikuchi and Kanamori (1991) to determine moment and slip subevents along the prescribed fault plane (Fig. 3). Modeled fault strike and dip is consistent with the focal mechanism determined by the Harvard CMT, and the fault geometry was extended from the hypocenter in both the northwest and southeast directions to account for the bilateral distribution of aftershocks. The coseismic vertical displacement fields derived from the two results are shown in Fig. 4. Both vertical coseismic displacement patterns shown in Fig. 4 compare favorably with the polarity of observed vertical displacement (black and red arrows) from the postevent field survey (Jaffe et al., 2005).

In the far field, source complexity is somewhat attenuated, owing to the effects of geometric spreading. For a simplified source of finite dimensions, the directivity pattern is characterized by significant beaming or wave focusing normal to fault strike (Ben-Menahem and Rosenman, 1972; Ward, 1982; Okal, 1988). Beaming from sources of finite dimensions reduces the far-field amplitudes as a function of fault length in comparison to a point-source representation with equivalent $M_{0}$ (Ward, 1982). Numerical modeling of far-field tsunami wave heights using variable slip at the source was calculated using the MOST model (Titov and González, 1997; Titov and Synolakis, 1998) and ETOPO2 bathymetry. Maximum tsunami amplitudes obtained from 
(a)

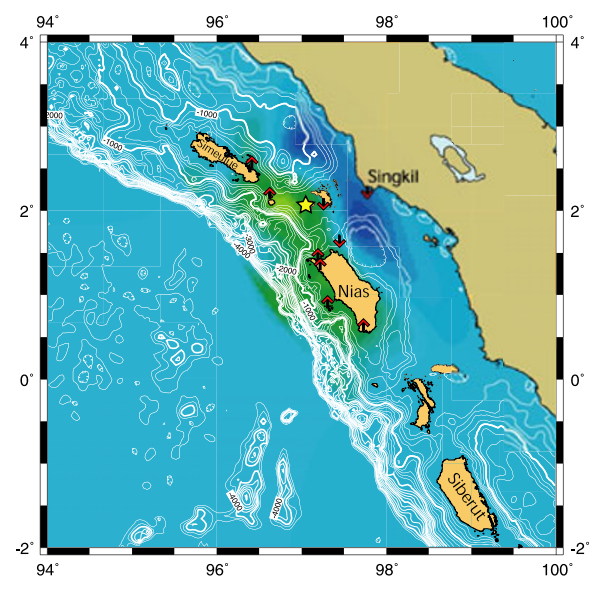

(b)

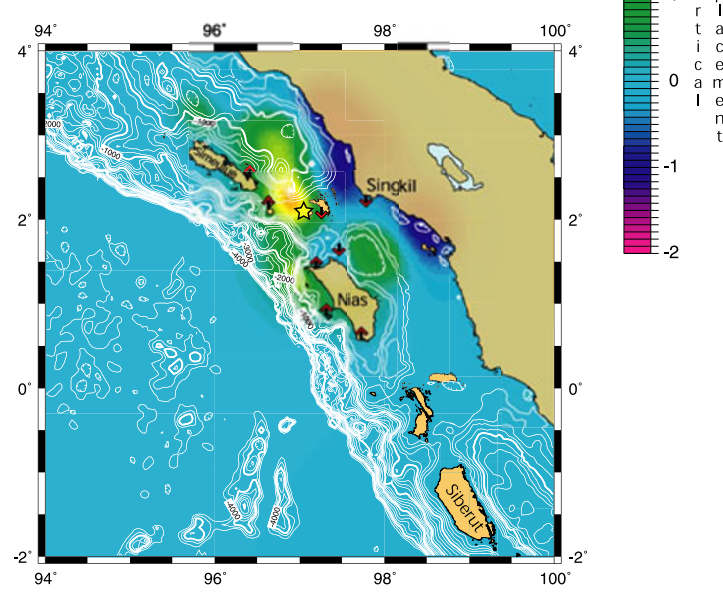

Fig. 4. Coseismic vertical displacement for the March 28, 2005 earthquake using (a) the slip distribution from Slip Model III (Ammon et al., 2005; $\mathrm{Ji}, 2005$ ) and (b) an inversion using $P$-waveforms for a large prescribed fault with geometry consistent with the strike and dip of the thrust mechanism from the Harvard CMT solution. Black and red arrows represent polarity of coseismic displacement (uplift—up, subsidence-down), as evidenced from post-earthquake field observations (Jaffe et al., 2005). Epicenter for the March 2005 earthquake shown by yellow star.

numerical modeling for both tsunamis illustrates this beaming effect and explains the distribution of affected regions distant from the source (Fig. 5). Because of a change in the orientation of the Sumatra-Andaman interplate thrust, there is a counter-clockwise rotation of the directivity pattern. For the December 2004 tsunami, beaming is primarily directed westward toward Sri Lanka and India and eastward toward Thailand. The tsunami recorded at the Hanimaadhoo station (Maldives) may have been partially blocked by India and Sri Lanka. (Similar to how the Maldives ridge attenuated tsunami energy propagating toward the north African coast, Fig. 5(a).) For the March 2005 tsunami, far-field beaming is directed to the southwest, away from nearby land masses. This is consistent with the ratio of farfield wave heights (peak-trough) recorded at tide gauge stations. Table 1 lists stations that recorded both tsunamis in counter-clockwise order, starting with Colombo, Sri Lanka, and ending with Cocos Island, Australia. All of these stations are 2-3.5 hours in travel time from the epicenters (Merrifield et al., 2005). The data indicate that the December/March ratio is highest for the northern stations and decreases toward Cocos Island, consistent with the predicted (a)

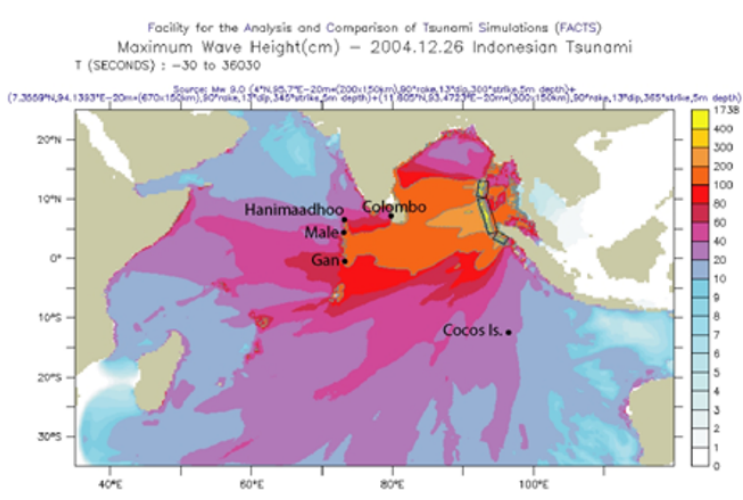

(b)

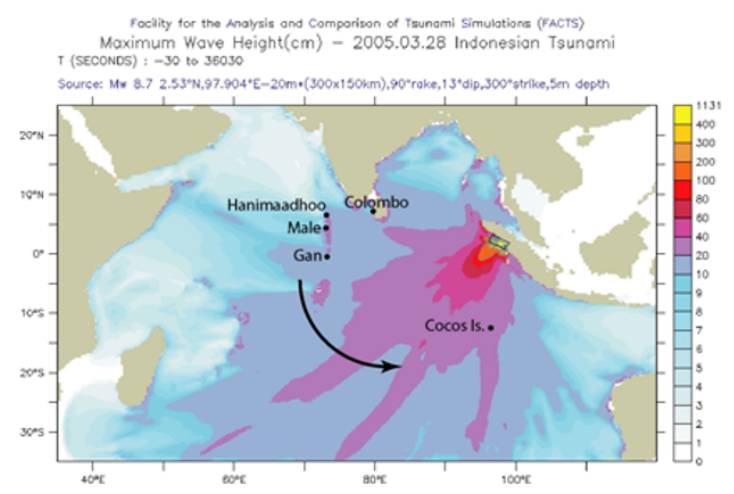

Fig. 5. Differences in maximum, far-field tsunami amplitudes for the December 2004 (a) and the March 2005 (b) tsunamis. Because of change in fault strike, directivity pattern is shifted counter-clockwise for the March tsunami in comparison to the December tsunami (as shown by arrow). Tide gauge stations listed in Table 1 annotated.

shift in the directivity pattern.

\section{Earthquake Physics}

Many of the differences between the two tsunamis relate to slip distribution patterns for the two earthquakes. Whereas point- and line-source parameterization of the earthquake can accurately predict far-field tsunami amplitudes, local tsunami runup is dependent on propagation paths from localized regions of sea floor displacement, arising from earthquake rupture complexity. The question, then, is why were the slip patterns for the December 2004 and March 2005 earthquakes so different?

One possible explanation are fixed heterogeneities of the inter-plate thrust, relating to fault geometry and topography of the down-going plate. The December and March earthquakes initiated near a prominent bend in the Sumatra interplate thrust, possibly resulting in concentration of stress. The 1971 Solomon Islands doublet may serve as an ana$\log$ in this regard (Schwartz et al., 1989). The topography of the down-going India plate, including the Ninety-East Ridge to the north also may have played a role in localization of strain release. In general, rupture heterogeneity of shallow subduction zone earthquakes relate to delineation of regions of frictional instability tied to topography of the subducting plate (Polet and Kanamori, 2000; Bilek and Lay, 2002).

Geometry and topographic variation are likely only part 
of the explanation, however. Rupture dynamics also is a strong influence on the final distribution of slip and slip complexity. Ruptures that nucleate at the depths of the December and March earthquakes more likely propagate up dip and for longer distances than shallow earthquakes are able to propagate down dip (Das and Scholz, 1983). Crack theory indicates that there is a critical distance where up-dip rupture will be unstable and break through to the surface, resulting in fundamentally different slip profile caused by the free-surface boundary condition (Dmowska and Kostrov, 1973; Rudnicki and Wu, 1995). In addition, whether or not rupture breaks through to the sea floor has a significant effect on the initial tsunami waveform (Geist and Dmowska, 1999).

Beyond fundamental crack mechanics, however, rateand state-dependent friction (Dieterich, 1992) can yield a variety of rupture modes and complexity, ranging from crack-like to narrow, self-healing slip pulses (Ben-Zion and Rice, 1997; Zheng and Rice, 1998; Nielsen and Carlson, 2000). Moreover, the non-linear nature of rupture propagation using realistic constitutive relations yields heterogeneous slip distributions, even in the absence of physical heterogeneities (Shaw, 1997; Shaw and Scholz, 2001). While the role of fixed heterogeneities related to fault structure and properties versus heterogeneity arising solely from the nonlinear dynamics of rupture propagation is a source of active controversy, it is becoming apparent that both factors are present and contribute significantly to observed variations in coseismic slip (Shaw, 2004). The important implication of this rich field of studies is that (a) whatever the mechanism, the final slip distribution of a rupture can be characterized as being self-affine (Andrews, 1980); and (b) this slip distribution, though deterministic and causal, is difficult to predict.

\section{Implications for Local Tsunami Warning Sys- tems and Hazard Assessments}

The preceding conclusions have obvious implications for local tsunami warning systems. Far-field tsunami warning continues to improve through faster ways to estimate $M_{0}$ (Tsuboi, 2000; Weinstein and Okal, 2005), using precomputed unit source models to produce short-term forecasts (Titov et al., 2005), and the search for other seismic discriminates to identify tsunami earthquakes (Okal and Newman, 2001). In contrast, for local tsunamis, it is difficult to obtain accurate, near real-time amplitude information from only point-source measurements of the earthquake. Local tsunami runup exhibits a significant degree of variability with respect to seismic moment. This is exemplified in the comparison of the Sumatra tsunamis presented here. Whereas the December 2004 tsunami resulted in mean and maximum runup similar to tsunamis from other earthquakes of comparable magnitude (e.g., 1964 Alaska earthquake) and consistent with empirical relationships (Abe, 1995), the March 2005 tsunami resulted in a much smaller than expected tsunami.

Similar conclusions were reached when comparing the tsunamis from the 1952 and 2003 Tokachi-Oki earthquakes. The hypocenters for both earthquakes were located very close together on the interplate thrust offshore Hokkaido, and their magnitudes were similar: $M_{w}=8.1$ and $M_{t}=$ 8.2 for the 1952 earthquake as estimated by Hirata et al. (2003) and Abe (1979), respectively, and $M_{w}=8.3$ and $M_{\mathrm{JMA}}=8.0$ for the 2003 earthquake as determined by the Harvard CMT and JMA, respectively. Not only were the mean and maximum runup values different as shown on Fig. 2(b), but the peaks in the runup distributions were near Akkeshi (near Kushiro) in 1952 and near Cape Erimo in 2003 (Tanioka et al., 2004). Hirata et al. (2004) suggests that the differences may be ascribed to differences in the slip distribution patterns. Much of the slip in 2003 was concentrated near the hypocenter (Yamanaka and Kikuchi, 2003), whereas there may have been a significant component of shallow slip near the trench for the 1952 earthquake (Hirata et al., 2003). Thus, the 1952 and 2003 Tokachi-Oki earthquake pair is similar to the December 2004 and March 2005 Sumatra earthquake pair in terms of how slip distribution affects tsunami runup.

Studies of both the Sumatra and Tokachi-Oki pairs of earthquakes point to the inherent variability of local tsunami runup with respect to simple epicenter and moment parameterization. The variability in tsunami generation and local tsunami runup that ultimately is caused by earthquake rupture complexity introduces significant uncertainty in local tsunami warning systems. Because tsunami warning systems have to adopt a conservative approach when issuing a warning, false alarms for local tsunamis appear to be inevitable. Determining reliable finite-source solutions in the time it takes tsunamis to arrive at shore is considerably difficult given current state of knowledge and technology. While rapid and reliable seismological methods are being developed to estimate tsunami generation potential, local tsunami hazard mitigation will also have to rely on offshore measurements of the tsunami and effective public education and emergency management programs.

\section{Conclusions}

Comparison of several scalar measures of tsunami generation indicate that the most readily available source parameter for tsunami warning, seismic moment $\left(M_{0}\right)$, is adequate for estimating far-field tsunami amplitudes. A slight change in the orientation of the fault results in a significant rotation in the tsunami beaming pattern, evidenced by a comparison of far-field tsunami amplitudes. For local tsunamis, in contrast, there is significant uncertainty in estimating mean and maximum tsunami runup from only $M_{0}$, as exemplified by the tsunamis generated by the December 2004 and March 2005 Sumatra earthquakes. We also examine other measures that rely on knowledge of the slip distribution for an earthquake. For the two Sumatra earthquakes, the maximum value of slip is not an adequate measure of tsunami generation, because of the effects of downdip position and overlying water depth where maximum slip occurred. Tsunami potential energy $\left(E_{T 0}\right)$, however, is approximately an order of magnitude different between the two earthquakes and is more representative of local tsunami severity. The specific distribution of runup is dependent on propagation paths and site-specific effects in the near field.

Acknowledgments. The authors sincerely thank Mohamed 
Chlieh and Chen Ji for sharing their inversion results and Bruce Jaffe for a compilation of field results. This paper greatly benefited from constructive reviews by Kenji Hirata, David Oppenheimer, Fred Pollitz, and an anonymous reviewer. We thank Arthur Tarr for the basemap used in Fig. 1. Maps in Fig. 4 were prepared using the GMT software (Wessel and Smith, 1995).

\section{References}

Abe, K., Size of great earthquake of 1837-1974 inferred from tsunami data, Journal of Geophysical Research, 84, 1561-1568, 1979.

Abe, K., Estimate of tsunami run-up heights from earthquake magnitudes, in Tsunami: Progress in Prediction, Disaster Prevention and Warning, edited by Y. Tsuchiya and N. Shuto, Kluwer Academic Publishers, Dordrecht, pp. 21-35, 1995.

Abe, K., Tsunami magnitude, http://www.drs.dpri.kyoto-u.ac.jp/sumatra/ index-e.html\#tsunami_mag, 2005.

Ammon, C. J., C. Ji, H. K. Thio, D. Robinson, S. Ni, V. Hjorleifsdottir, H. Kanamori, T. Lay, S. Das, D. Helmberger, G. Ichinose, J. Polet, and D. Wald, Rupture process of the 2004 Sumatra-Andaman earthquake, Science, 308, 1133-1139, 2005.

Andrews, D. J., A stochastic fault model 1. Static case, Journal of Geophysical Research, 85, 3867-3877, 1980.

Banerjee, P., F. F. Pollitz, and R. Bürgmann, The size and duration of the Sumatra-Andaman earthquake from far-field static offsets, Science, 308, 1769-1772, 2005

Ben-Menahem, A. and M. Rosenman, Amplitude patterns of tsunami waves from submarine earthquakes, Journal of Geophysical Research, 77, 3097-3128, 1972.

Ben-Zion, Y. and J. R. Rice, Dynamic simulations of slip on a smooth fault in an elastic solid, Journal of Geophysical Research, 102, 17,77117,784, 1997.

Beresnev, I. A., Uncertainties in finite-fault slip inversions: To what extent to believe? (A critical review), Bulletin of the Seismological Society of America, 93, 2445-2458, 2003.

Bilek, S. L. and T. Lay, Tsunami earthquakes possibly widespread manifestations of frictional conditional stability, Geophysical Research Letters, 29, doi:10.1029/2002GL015215, 2002.

Chlieh, M., J. P. Avouac, K. Sieh, L. Prawirodirdjo, Y. Bock, V. Hjorleifsdottir, C. Ji, H. Hebert, A. Sladen, D. Natawidjaja, C. Subarya, and J. Galetzka, Coseismic slip and afterslip associated to the Mw9.14 AcehAndaman earthquake [abs.], Eos, Transactions American Geophysical Union, 86, 2005

Das, S. and C. H. Scholz, Why large earthquakes do no nucleate at shallow depths, Nature, 305, 621-623, 1983.

Dieterich, J. H., Earthquake nucleation on faults with rate- and statedependent strength, Tectonophysics, 211, 115-134, 1992.

Dmowska, R. and B. V. Kostrov, A shearing crack in a semi-space under plane strain conditions, Archives of Mechanics, 25, 421-440, 1973.

Geist, E. L., Local tsunamis and earthquake source parameters, Advances in Geophysics, 39, 117-209, 1999.

Geist, E. L., Complex earthquake rupture and local tsunamis, Journal of Geophysical Research, 107, doi:10.1029/2000JB000139, 2002.

Geist, E. L. and R. Dmowska, Local tsunamis and distributed slip at the source, Pure and Applied Geophysics, 154, 485-512, 1999.

Hirata, K., E. L. Geist, K. Satake, Y. Tanioka, and S. Yamaki, Slip distribution of the 1952 Tokachi-Oki earthquake (M 8.1) along the Kuril Trench deduced from tsunami waveform inversion, Journal of Geophysical Research, 108, doi:10.1029/2002JB001976, 2003.

Hirata, K., Y. Tanioka, K. Satake, S. Yamaki, and E. L. Geist, The tsunami source area of the 2003 Tokachi-oki earthquake estimated from tsunami travel times and its relationship to the 1952 Tokachi-oki earthquake, Earth Planets Space, 56, 367-372, 2004

Iida, K., D. C. Cox, and G. Pararas-Carayannis, Preliminary catalog of tsunamis occurring in the Pacific Ocean, 67-10, Hawaii Institute of Geophysics, University of Hawaii, Honolulu, pp. 131, 1967.

Ishii, M., P. M. Shearer, H. Houston, and J. E. Vidale, Extent, duration and speed of the 2004 Sumatra-Andaman earthquake imaged by the Hi-Net array, Nature, 435, 933-936, 2005.

Jaffe, B. E., G. S. Prasetya, J. C. Borrero, G. Gelfenbaum, P. Ruggiero, R. Morton, B. Peters, E. Kingsley, S. Diposaptono, R. Hidayat, Lukianto, Widjokongko, V. V. Titov, A. Moore, B. McAdoo, L. Dengler, B. Higman, and E. Yulianto, USGS scientists in Sumatra studying recent tsunamis: March 30-April 26, http://walrus.wr.usgs.gov/news/ field.html, 2005 .

Ji, C., Updated result of the 05/03/28 (Mw 8.5), Sumatra earthquake, http://
www.gps.caltech.edu/\%7Ejichen/Earthquake/2005/sumatra/sumatra. html, 2005.

Johnson, J. M. and K. Satake, Source parameters of the 1957 Aleutian earthquake from tsunami waveforms, Geophysical Research Letters, 20, 1487-1490, 1993.

Kajiura, K., The leading wave of a tsunami, Bulletin of the Earthquake Research Institute, 41, 535-571, 1963.

Kajiura, K., Tsunami energy in relation to parameters of the earthquake fault model, Bulletin of the Earthquake Research Institute, 56, 415-440, 1981.

Kikuchi, M. and H. Kanamori, Inversion of complex body waves-III, Bulletin of the Seismological Society of America, 81, 2335-2350, 1991. Krüger, F. and M. Ohrnberger, Tracking the rupture of the $M_{w}=9.3$ Sumatra earthquake over $1,150 \mathrm{~km}$ at teleseismic distance, Nature, $\mathbf{4 3 5}$, 937-939, 2005.

Lander, J. F., Tsunamis affecting Alaska 1737-1996, No. 31, U.S. Department of Commerce, National Oceanic and Atmospheric Administration, Boulder, Colorado, pp. 195, 1996.

Lay, T., H. Kanamori, C. J. Ammon, M. Nettles, S. N. Ward, R. C. Aster, S. L. Beck, S. L. Bilek, M. R. Brudzinski, R. Butler, H. R. DeShon, G. Ektröm, K. Satake, and S. A. Sipkin, The great Sumatra-Andaman earthquake of 26 December 2004, Science, 308, 1127-1133, 2005.

Li, Y., Tsunamis: Non-Breaking and Breaking Solitary Wave Run-Up, KHR-60, W. M. Keck Laboratory of Hydraulics and Water Resources, California Institute of Technology, Pasadena, California, pp. 249, 2000.

Mei, C. C., The Applied Dynamics of Ocean Surface Waves, Advanced Series on Ocean Engieering, 1, World Scientific, Singapore, pp. 740, 1989.

Merrifield, M. A., Y. L. Firing, T. Aarup, W. Agricole, G. Brundrit, D. Chang-Seng, R. Farre, B. Kilonsky, W. Knight, L. Kong, C. Magori, P. Manurung, C. S. McCreery, W. Mitchell, S. Pillay, F. Schindelé, F. Shillington, L. Testut, E. M. S. Wijeratne, P. Caldwell, J. Jardin, S. Nakahara, F. Y. Porter, and N. Turetsky, Tide gauge observations of the Indian Ocean tsunami, December 26, 2004, Geophysical Research Letters, 32, doi:10.1029/2005GL022610, 2005.

Newcomb, K. R. and W. R. McCann, Seismic history and seismotectonics of the Sunda arc, Journal of Geophysical Research, 92, 421-439, 1987.

Newman, A. V. and S. L. Bilek, A comparison of the March 28, 2005 and December 26, 2004 Sumatran earthquakes: Near-trench rupture exciting tsunami generation? [abs.], Eos, Transactions American Geophysical Union, 86(18), Joint Assembly Supplement, Abstract U53B-04, 2005.

Nielsen, S. B. and J. M. Carlson, Rupture pulse characterization: Selfhealing, self-similar, expanding solutions in a continuum model of fault dynamics, Bulletin of the Seismological Society of America, 90, 14801497, 2000

Okada, Y., Surface deformation due to shear and tensile faults in a halfspace, Bulletin of the Seismological Society of America, 75, 1135-1154, 1985.

Okal, E. A., Seismic parameters controlling far-field tsunami amplitudes: A review, Natural Hazards, 1, 67-96, 1988.

Okal, E. A. and A. V. Newman, Tsunami earthquakes: the quest for a regional signal, Physics of the Earth and Planetary Interiors, 124, 45$70,2001$.

Park, J., T. A. Song, J. Tromp, E. A. Okal, S. Stein, G. Roult, E. Clevede, G. Laske, H. Kanamori, P. Davis, J. Berger, C. Braitenberg, M. Van Camp, X. Lei, H. Sun, H. Xu, and S. Rosat, Earth's free oscillations excited by the 26 December 2004 Sumatra-Andaman earthquake, Science, 308, 1139-1144, 2005.

Pelayo, A. M. and D. A. Wiens, Tsunami earthquakes: Slow thrust-faulting events in the accretionary wedge, Journal of Geophysical Research, 97, 15,321-15,337, 1992.

Polet, J. and H. Kanamori, Shallow subduction zone earthquakes and their tsunamigenic potential, Geophysical Journal International, 142, 684 $702,2000$.

Rudnicki, J. W. and M. Wu, Mechanics of dip-slip faulting in an elastic half-space, Journal of Geophysical Research, 100, 22,173-22,186, 1995

Satake, K., Tsunamis, in International Handbook of Earthquake and Engineering Seismology, edited by W. H. K. Lee, H. Kanamori, P. C. Jennings and C. Kisslinger, pp. 437-451, Academic Press, San Diego, 2002.

Schwartz, S. Y., T. Lay, and L. J. Ruff, Source process of the great 1971 Solomon Islands doublet, Physics of the Earth and Planetary Interiors, 56, 294-310, 1989

Shaw, B. E., Model quakes in the two-dimensional wave equations, Journal of Geophysical Research, 102, 27,367-27,377, 1997. 
Shaw, B. E., Dynamic heterogeneities versus fixed heterogeneities in earthquake models, Geophysical Journal International, 156, 275-286, 2004.

Shaw, B. E. and C. H. Scholz, Slip-length scaling in large earthquakes: Observations and theory and implications for earthquake physics, Geophysical Research Letters, 28, 2995-2998, 2001.

Soloviev, S. L., Recurrence of tsunamis in the Pacific, in Tsunamis in the Pacific Ocean, edited by W. M. Adams, pp. 149-163, East-West Center Press, Honolulu, 1970.

Stein, S. and E. A. Okal, Speed and size of the Sumatra earthquake, Nature, 434, 581-582, 2005.

Synolakis, C. E., The runup of solitary waves, Journal of Fluid Mechanics, 185, 523-545, 1987.

Tadepalli, S. and C. E. Synolakis, Model for the leading waves of tsunamis, Physical Review Letters, 77, 2141-2144, 1996.

Tanioka, Y. and K. Satake, Tsunami generation by horizontal displacement of ocean bottom, Geophysical Research Letters, 23, 861-865, 1996.

Tanioka, Y., Y. Nishimura, K. Hirakawa, F. Imamura, I. Abe, Y. Abe, K. Shindou, H. Matsutomi, T. Takahashi, K. Imai, K. Harada, Y. Namegawa, Y. Hasegawa, Y. Hayashi, F. Nanayama, T. Kamataki, Y. Kawata, Y. Fukasawa, S. Koshimura, Y. Hada, Y. Azumai, K. Hirata, A. Kamikawa, A. Yoshikawa, T. Shiga, M. Kobayashi, and S. Masaka, Tsunami run-up heights of the 2003 Tokachi-oki earthquake, Earth Planets Space, 56, 359-365, 2004.

Titov, V. V. and F. I. González, Implementation and testing of the Method of Splitting Tsunami (MOST) model, ERL PMEL-112, NOAA, pp. 11, 1997.

Titov, V. V. and C. E. Synolakis, Numerical modeling of tidal wave runup, Journal of Waterway, Port, Coastal, and Ocean Engineering, 124, 157$171,1998$.

Titov, V. V., F. I. González, E. N. Bernard, J. E. Ebel, H. O. Mofjeld, J. C. Newman, and A. J. Venturato, Real-time tsunami forecasting: Challenges and solutions, Natural Hazards, 35, 40-58, 2005.
Tsai, V. C., M. Nettles, G. Ektröm, and A. M. Dziewonski, Multiple CMT source analysis of the 2004 Sumatra earthquake, Geophysical Research Letters, 32, doi:10.1029/2005GL023813, 2005.

Tsuboi, S., Application of Mwp to tsunami earthquake, Geophysical Research Letters, 27, 3105-3108, 2000.

Tsuboi, S., K. Abe, K. Takano, and Y. Yamanaka, Rapid determination of Mw from broadband $\mathrm{P}$ waveforms, Bulletin of the Seismological Society of America, 85, 606-613, 1995.

Ward, S. N., Relationships of tsunami generation and an earthquake source, Journal of Physics of the Earth, 28, 441-474, 1980.

Ward, S. N., On tsunami nucleation II. An instantaneous modulated line source, Physics of the Earth and Planetary Interiors, 27, 273-285, 1982.

Ward, S. N., Tsunamis, in The Encyclopedia of Physical Science and Technology, edited by R. A. Meyers, pp. 175-191, Academic Press, 2002.

Weinstein, S. A. and E. A. Okal, The mantle wave magnitude $M_{m}$ and the slowness parameter $\Theta$ : Five years of real-time use in the context of tsunami warning, Bulletin of the Seismological Society of America, 95, 779-799, 2005.

Wessel, P. and W. H. F. Smith, New version of the Generic Mapping Tools released, Eos, Transactions American Geophysical Union, 76, F329, 1995.

Yamanaka, Y. and M. Kikuchi, Source process of the recurrent Tokachioki earthquake on September 26, 2003 inferred from teleseismic body waves, Earth Planets Space, 55, e21-e24, 2003.

Zheng, G. and J. R. Rice, Conditions under which velocity-weakening friction allows a self-healing versus a cracklike mode of rupture, Bulletin of the Seismological Society of America, 88, 1466-1483, 1998.

E. L. Geist (e-mail: egeist@usgs.gov), S. L. Bilek, D. Arcas, and V. V. E.
Titov 